\title{
Prevalence of Bronchial Asthma Among Secondary School Students in Dhaka City
}

S.Sarkar ${ }^{1}$, S.J.Mumu ${ }^{2}$, M.Shahjahan ${ }^{3}$, M.S. Flora ${ }^{4}$, M.A. Hafez ${ }^{5}$

\begin{abstract}
:
Asthma is a substantial health problem among children and adults worldwide, many countries having increasing prevalence of bronchial asthma. Within our knowledge no epidemiological studies have addressed the burden of bronchial asthma among secondary school students in Bangladesh. This study aimed to determine the prevalence of bronchial asthma and its associated factors among secondary school students. A cross sectional study was conducted from January 2010 to June 2010. Two hundred and fifty secondary school students from class VI to class $X$ were randomly selected from a purposively selected secondary school at Mirpur in Dhaka city. International Studies of Asthma and Allergies in Childhood (ISAAC) core asthma questionnaire was self administered for diagnosis of asthma. Out of 250 students male was $128(51 \%)$ and female was $122(49 \%)$, mean age of the respondents was $12.9 \pm 1.2$ years. Minimum education level of respondents' parents were primary, half of the respondents' father's education level was graduate and above (52.8\%) and half of the respondents' mother's education level was high school (58.4\%). The prevalence of bronchial asthma was 11.6\% (95\% CI: 7.64\% to $15.56 \%$ ). The proportion of bronchial asthma was higher in male than female $(15.6 \%$ vs $7.4 \%, p<0.05)$. Bronchial asthma was found significantly higher among the students who had attacks of pneumonia during their childhood (under class VI) compared to children who did not (23.8\% vs $9.1 \%$, $p<0.05)$. About $11 \%$ students were exposed to passive smoking. Passive smoking significantly associated with bronchial asthma $(p<0.038)$. Risk indicators associated with bronchial asthma included history of pneumonia $(O R=3.109$, 95\%CI: 1.32 to 7.29$)$, maternal asthma $(O R=2.73,95 \% C I$ : 1.05 to 7.11$)$ and male sex $(O R=2.32,95 \% C I$ : 1.01 to 5.33).This study showed that the prevalence of bronchial asthma was high among secondary school students than common people. Passive smoking, history of pneumonia,
\end{abstract}

1. Dr. Shamim Sarkar, Department of Epidemiology, Bangladesh Institute of Health Sciences (BIHS) Dhaka.

2. Dr. Shirin Jahan Mumu, Assistant Professor, Department of Epidemiology, Bangladesh Institute of Health Sciences (BIHS) Dhaka

3. Dr. Md Shahjahan Mia, Assistant Professor, Department of Epidemiology, Bangladesh Institute of Health Sciences (BIHS) Dhaka.

4. Dr. Meerjady Sabrina Flora, Associate Professor, Department of Epidemiology, Bangladesh Institute of Health Sciences (BIHS) Dhaka.

5. Dr. M.A. Hafez, Professor \& Head of the Department of Epidemiology, Bangladesh Institute of Health Sciences (BIHS) Dhaka.

Corresponding Author:

Dr. Shamim Sarkar

Research Fellow, CDD, ICDDRB, Mohakhali, Dhkaka-1212

E-mail: Shamim.sarkar@icddrb.org maternal asthma and male sex were found to be significant risk indicators for bronchial asthma. So that greater efforts are needed to prevent childhood pneumonia and passive smoking to reduce the chances of subsequent development of bronchial asthma.

Keywords: Bronchial asthma, secondary school students, risk indicator, ISAAC.

\section{Introduction:}

Asthma is one of the important public health problems worldwide with wide differences in prevalence and severity throughout the world. The World Health Organization (WHO) estimates that 235 million people currently suffer from bronchial asthma. ${ }^{1}$ Bronchial asthma is a chronic inflammatory disease of airways is presented with wheezing, breathlessness, chest tightness and coughing. ${ }^{1}$ The fundamental causes of bronchial asthma are not completely understood, but strongest risk factors for developing bronchial asthma are a combination of genetic predisposition with environmental exposure to inhaled substances and particles that may provoke allergic reactions or irritate the airways. ${ }^{1}$ The asthma prevalence studies done across the globe have reported a male predominance of the disease. ${ }^{2}$ Whose parents had bronchial asthma, those children more likely to get bronchial asthma. ${ }^{3}$ Passive parental smoking has been shown to be linked to respiratory diseases. 4 The passive smoking could well be the most important 'noncommunicable' environmental factor involved in the etiology of early asthma. ${ }^{1-6}$

Several cross-sectional studies conducted over the past 20-30 years indicate an increased prevalence of allergic respiratory diseases worldwide, particularly among children in high income countries, for example, $29 \%$ in the United kingdom, $30 \%$ in Australia, 30\% in New Zealand and 21\% in United States of America. ${ }^{7,8}$ It has been observed that wide variations exist between countries in prevalence of asthma, its clinical presentation and natural history. ${ }^{9}$

In south East Asia region, bronchial asthma has become a substantial public health problem. ${ }^{10}$ The prevalence of school children bronchial asthma in south east Asia region like China (1-2.4\%), Hong Kong (7.2-8\%), Indonesia (2.38.2\%), Malaysia (13.8\%), and India (7.2\%).10-13 The First National Asthma Prevalence Study (FNAP) in Bangladesh in 1999, showed that about 7 million people $(5.2 \%$ of the population) are suffering from current asthma in at least three episodes of asthma attack in one year; $90 \%$ of whom do not take modern treatment. ${ }^{14}$ When it is under-diagnosed and under-treated, creating a substantial burden to individuals and families and possibly restricting individuals' activities for a lifetime. Although bronchial asthma causes a great deal of morbidity among children in Bangladesh, a few epidemiological studies addressed this problem. ${ }^{17}$ The objectives of this study were to determine the overall prevalence of bronchial asthma and their risks associated with it among secondary school students in Dhaka city. 


\section{Materials and Methods:}

Under a cross sectional study design 250 secondary school students (class VI to X, both boys and girls) were selected the "Model Academy" a secondary school which was selected purposively and located in Dhaka city of Bangladesh. The study was conducted from January 2010 to June 2010. Sample size was calculated by using the formula of estimating the proportion with specified absolute precision which was 250 . Among the 250 students, 60 were from class VI, 66 from class VII, 54 from class VIII, 42 from class IX and 28 from class $\mathrm{X}$. The students were selected randomly with calculation of proportionate size of students from different class of students in the secondary school students by using random number table.

The data collection was performed by using structured questionnaire that was International Study of Asthma and Allergies in Childhood (ISAAC) asthma questionnaire. Questionnaire consisted of two parts; Part A included sociodemographic information of students and their parents, monthly family education, history smoking and history of passive smoking, history of childhood pneumonia, history of parents' asthma and eczema. Part B consisted of ISAAC core asthma questionnaire. The asthma module comprises eight questions. Asthma prevalence was determined by current (last 12 months) wheezing episodes. They were also asked whether they have ever been diagnosed for asthma by doctor, and treated in last 12 months.

Individual questionnaire was checked for completeness prior to the date of data collection by the researcher. Data was managed accordingly and analyzed by SPSS version 11.5 . Prevalence of bronchial asthma was calculated with $95 \%$ confidence interval. Chi-square test was done at the 5\% level of significance to find out the association between bronchial asthma and associated risk. Odds ratios for bronchial asthma for the independent variables were calculated in a logistic regression model.

Ethical committee of Diabetic Association of Bangladesh reviewed the research proposal and approved. Written permission was obtained from the Headmaster of the "Model academy" Secondary school for the collection of data. Before distributing the questionnaire among students, study objectives, methods, risks and benefits were explained and then written informed consent were taken.

\section{Results:}

Out of 250 students, 128 (51\%) were male and 122 (49\%) were female. Half of the respondent's belonged to $13-15$ years age group, $138(55.2 \%)$ and rest of them were above 15 years age. The median monthly family income was Tk15,000 (4,000-50,000). Half of the respondents' 126 (50.4\%) fathers' educational status was graduate and above level, and half of the mothers 146 (58.4\%) educational status was high school level. About half of the respondent's fathers, $114(46 \%)$ occupation were government services, and most of the respondents' 216 (86\%) mother were housewife. The overall prevalence of bronchial asthma among secondary school students was $11.6 \%$ (95\% CI: 7.64\%-15.56\%). Bronchial asthma was more prevalent $(15.6 \%)$ in male than female (7.4\%) students (Figure-1). Prevalence of bronchial asthma was significantly higher among students who had attacks of pneumonia during their childhood compared to children who did not have $(23.8 \%$ vs $9.1 \%, \mathrm{p}<0.007)$. We found passive smoking significantly associated with bronchial asthma $(\mathrm{p}<0.038)$. Table-2)

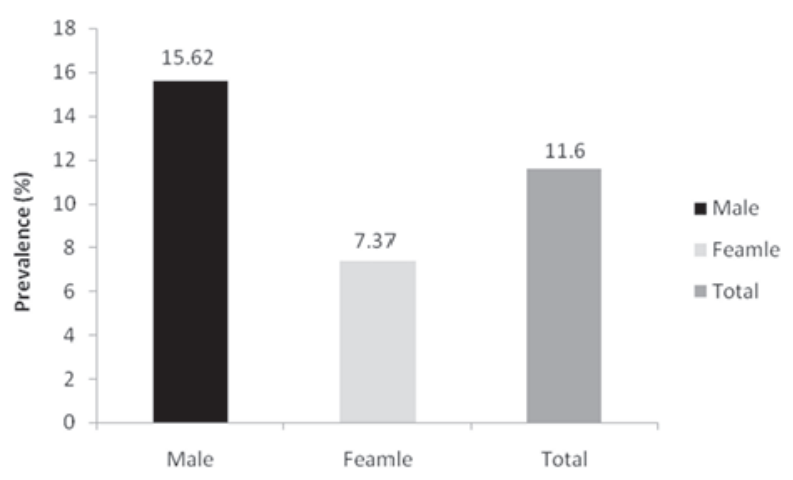

Figure 1: Prevalence of bronchial asthma in the study population

Table 1: Characteristics of the respondents $(n=250)$

\begin{tabular}{|c|c|c|}
\hline Characteristics & Number (n) & Percentage (\%) \\
\hline Age $($ Mean $\pm S D)$ in years & $12.9 \pm 1.2$ & - \\
\hline Sex & & \\
\hline Male & 128 & 51 \\
\hline Female & 122 & 49 \\
\hline Monthly family income (Median) in Tk & $15,000(4,000-50,000)$ & - \\
\hline $\begin{array}{l}\text { Respondents father education level } \\
\text { Primary education } \\
\text { High school } \\
\text { Graduate \& above } \\
\text { Others }\end{array}$ & $\begin{array}{l}17 \\
101 \\
126 \\
6\end{array}$ & $\begin{array}{l}6.8 \\
40.4 \\
50.4 \\
2.4\end{array}$ \\
\hline $\begin{array}{l}\text { Respondents mother education level } \\
\text { Primary education } \\
\text { High school } \\
\text { Graduate \& above } \\
\text { Others }\end{array}$ & $\begin{array}{l}24 \\
146 \\
77 \\
3\end{array}$ & $\begin{array}{l}9.6 \\
58.4 \\
30.8 \\
1.2\end{array}$ \\
\hline $\begin{array}{l}\text { Smoking status of respondents } \\
\text { Yes } \\
\text { No }\end{array}$ & $\begin{array}{l}3 \\
247\end{array}$ & $\begin{array}{l}1.2 \\
98.8\end{array}$ \\
\hline $\begin{array}{l}\text { Respondend' father smoking status } \\
\text { Yes } \\
\text { No }\end{array}$ & $\begin{array}{l}64 \\
186\end{array}$ & $\begin{array}{l}25.6 \\
74.4\end{array}$ \\
\hline $\begin{array}{l}\text { Respondents' mother smoking status } \\
\text { Yes } \\
\text { No }\end{array}$ & $\begin{array}{l}2 \\
248 \\
\end{array}$ & $\begin{array}{l}0.8 \\
99.2\end{array}$ \\
\hline $\begin{array}{l}\text { History of childhood pneumonia of respondents } \\
\text { Yes } \\
\text { No }\end{array}$ & $\begin{array}{l}42 \\
208\end{array}$ & $\begin{array}{l}16.8 \\
83.2\end{array}$ \\
\hline $\begin{array}{l}\text { Respondents' asthma diagnosed by doctor } \\
\text { Yes } \\
\text { No }\end{array}$ & $\begin{array}{l}29 \\
221\end{array}$ & $\begin{array}{l}11.6 \\
88.4\end{array}$ \\
\hline
\end{tabular}


Table 2: Factor associated with bronchial asthma $(n=250)$

\begin{tabular}{|c|c|c|c|c|}
\hline Factor & $\begin{array}{l}\text { Bronchial asthma } \\
\text { n }(\%)\end{array}$ & $\begin{array}{l}\text { No bronchial } \\
\text { asthma, } \mathrm{n}(\%)\end{array}$ & Chi-square value & P value \\
\hline \multicolumn{5}{|l|}{ Sex } \\
\hline Male & $20(15.6)$ & $108(84.4)$ & 4.14 & $0.042 *$ \\
\hline Female & $9(7.4)$ & $113(92.6)$ & & \\
\hline \multicolumn{5}{|l|}{ Age (years) } \\
\hline $10-12$ & $8(9.1)$ & $80(90.9)$ & & 0.471 \\
\hline $13-15$ & $21(13.3)$ & $137(86.7)$ & 1.50 & \\
\hline $16-18$ & $0(0)$ & $4(100)$ & & \\
\hline \multirow{2}{*}{\multicolumn{5}{|c|}{$\begin{array}{l}\text { Monthly family } \\
\text { income (Tk) }\end{array}$}} \\
\hline & & & & \\
\hline$<15000$ & $7(8)$ & $80(92.0)$ & 1.64 & 0.20 \\
\hline$>15000$ & $22(13.5)$ & $141(86.7)$ & & \\
\hline \multirow{2}{*}{\multicolumn{5}{|c|}{$\begin{array}{l}\text { History of childhood } \\
\text { pneumonia }\end{array}$}} \\
\hline & & & & \\
\hline Yes & $10(23.8)$ & $32(76.2)$ & 7.33 & $0.007^{*}$ \\
\hline № & $19(9.1)$ & $189(90.9)$ & & \\
\hline \multirow{2}{*}{\multicolumn{5}{|c|}{$\begin{array}{l}\text { History of paternal } \\
\text { asthma }\end{array}$}} \\
\hline & & & & \\
\hline Yes & $3(21.4)$ & $11(78.6)$ & 1.39 & 0.212 \\
\hline No & $26(11.0)$ & $210(89.0)$ & & \\
\hline \multirow{2}{*}{\multicolumn{5}{|c|}{$\begin{array}{l}\text { History of maternal } \\
\text { asthma }\end{array}$}} \\
\hline & & & & \\
\hline Yes & $7(23.3)$ & $23(76.7)$ & 4.57 & $0.032 *$ \\
\hline No & $22(10.0)$ & $198(90.0)$ & & \\
\hline \multirow{2}{*}{\multicolumn{5}{|c|}{$\begin{array}{l}\text { History of paternal } \\
\text { eczema }\end{array}$}} \\
\hline & & & & \\
\hline Yes & $1(16.7)$ & $5(83.3)$ & 0.15 & 0.527 \\
\hline No & $28(11.5)$ & $216(88.5)$ & & \\
\hline \multirow{2}{*}{\multicolumn{5}{|c|}{$\begin{array}{l}\text { History of maternal } \\
\text { eczema }\end{array}$}} \\
\hline & & & & \\
\hline Yes & $1(22.0)$ & $4(80.0)$ & 0.35 & 0.463 \\
\hline No & $28(11.4)$ & $217(88.6)$ & & \\
\hline \multicolumn{5}{|l|}{ Passive smoking } \\
\hline Yes & $3(33.3)$ & $6(66.7)$ & 4.30 & $0.038^{*}$ \\
\hline No & $26(10.8)$ & $215(89.2)$ & & \\
\hline *Indicate significant & & & & \\
\hline
\end{tabular}

*Indicate significant

Table 3: Logistics regression analysis to predict factor associated with bronchial asthma $(n=250)$

\begin{tabular}{|l|l|l|l|l|}
\hline $\begin{array}{l}\text { Dependent } \\
\text { variable }\end{array}$ & Independent variable* & Odds ratio & $\mathbf{9 5 \%}$ CI & P value \\
\hline Bronchial asthma & Male & 2.32 & $1.01-5.33$ & 0.042 \\
& Childhood pneumonia & 3.10 & $1.32-7.29$ & 0.007 \\
& Maternal asthma & 2.739 & $1.05-7.11$ & 0.032 \\
\hline
\end{tabular}

*Reference category: Female, no childhood pneumonia, no maternal asthma, no passive smoking
Factor associated with bronchial asthma among secondary school students were male sex $(\mathrm{OR}=2.32,95 \% \mathrm{CI}$ : 1.01-5.33), history of childhood pneumonia $(\mathrm{OR}=3.10,95 \% \mathrm{CI}$ : 1.325 7.291), maternal asthma ( $\mathrm{OR}=2.739,95 \% \mathrm{CI}: 1.055-7.110)$ (Table 3). Age of students, education of parents, monthly family income, paternal asthma and eczema, maternal eczema were not associated with bronchial asthma (Table-2)

\section{Discussion:}

Prevalence of bronchial asthma among secondary school students in Dhaka city was found to be $11.6 \%$. This prevalence was higher than the prevalence observed in an earlier study conducted in 2000 in urban and rural areas in Dhaka district. ${ }^{15}$ Another study conducted in rural Bangladeshi children found that the prevalence of bronchial asthma was $16.1 \%$ in the year 2001. It was higher than our study, because they conducted this study in the area where the incidence of acute respiratory infections (ARI), diarhhoea and malnutrition was high. ${ }^{16}$ In our study the prevalence of bronchial asthma among secondary school students was high which may be explained by different level of air pollution, exposure to allergens and climate condition. Global warming has also got important role play in the increasing of allergic disorders worldwide over the last three decades. Increased temperature and carbon dioxide $(\mathrm{CO} 2)$ production due to climate change result in increased production of pollens and fungal spores that could exacerbate symptoms of allergic diseases. ${ }^{17}$

In this study bronchial asthma was found higher in male respondents than female respondents. The exact reason for male predominance is not known but several explanations have been offered. Male predominance may be related to a greater degree of bronchial lability in males. Airways in boys are smaller in comparison to their lung sizes when compared to girls. ${ }^{18}$ In a study conducted in Newzealand showed higher rates of sensitivity to indoor allergens among males aged 13 years than their female counterparts as assessed by the skin prick test. ${ }^{19}$ May be boys are more exposed to air pollution than girls, because they spend in outside than girls. Similar result was found in India and Japan. ${ }^{20-21}$

This study found that the school children had higher risk for bronchial asthma who suffered from pneumonia at early childhood life. In Bangladesh, acute lower respiratory infections (ALRI) are major cause of morbidity and mortality. ${ }^{22}$ These children have higher risk of developing asthma in subsequent years. ${ }^{23}$ Among various infectious agents during early life, respiratory syncital virus (RSV) is well known to cause asthma in later life. ${ }^{24,26}$ The study did not examine the etiologic agents. The results of the present study are compatible with these observations, indicating the need for attention to post ALRI wheezing to curve the increase of wheezing in children. ${ }^{25}$

This study found significant association between maternal asthma and children bronchial asthma. There are many studies which found history of maternal asthma is associated with bronchial asthma among children. ${ }^{16,20}$ That influences is more on children than paternal influence, particularly in children less than five years of age possibly due to transplacental transfer of allergens or cytokines to the fetus.27 Passive smoking was significantly associated with bronchial 
asthma among secondary school students. Passive smoking is likely to be the cause of the greater bronchial irritability and the increased bronchial obstruction, which are leads to asthmatic symptom among students. ${ }^{28}$

The association between socio-economic status and bronchial asthma was not statistically significant in this study. However the study conducted by K Zaman et al and observed association between monthly family income and bronchial asthma. These factors may cause poor nutrition and predispose for pneumonia which contributes to the subsequent development of wheezing. ${ }^{16}$

This study did not find any significant association between age, parental eczema, and paternal asthma with bronchial asthma among school students.

This study had some limitations, such as, use of ISAAC questionnaire for the diagnosis of bronchial asthma rather than utilizing tests for bronchial hyperresponsiveness and the study was conducted in a secondary school student only.

In conclusion, this study showed higher prevalence of bronchial asthma among secondary school students in Dhaka city. Maternal asthma, history of childhood pneumonia and passive smoking act as a risk indicator for bronchial asthma among secondary school students. Male had higher risk for getting bronchial asthma than female. So that greater efforts are needed to prevent childhood pneumonia and passive smoking to reduce the chances of subsequent development of bronchial asthma. Globally there is limited study on interventions to prevent bronchial asthma, the health education intervention may prevent bronchial asthma among secondary school students.

\section{Acknowledgements:}

We are grateful to the Model Academy School authority and the students for their support to conduct this study. We also thankful to Bangladesh Institute of Health Sciences (BIHS) for allowing us to conducted this study.

\section{References:}

1. Fact sheet of asthma, available at: http://www.who.int/mediacentre/factsheets/fs307/en/ accessed on June 21,2011

2. Behl RK, Kashyap S, Sarkar M et al. Prevalence of bronchial asthma in school children of 6-13 years of age in Shimla city. The Indian journal of chest diseases \& allied sciences 210; 52(3): 145.

3. Sibbald B, Horn ME, Brain et al. Genetic factors in childhood asthma. Thorax 1980; 35(9): 671.

4. Colley JRT, Holland WW, Corkhill RT et al. Influence of passive smoking and parental phlegm on pneumonia and bronchitis in e arly childhood. The Lancet 1974; 304(7888): 1031-1034.

5. Pullan CR, Toms GL, Martin AJ et al. Breast-feeding and respiratory syncytial virus infection. British medical journal 1980; 281(6247):1034.

6. Webb MS, Henry RL, Milner AD et al. Continuing respiratory problems three and a half years after acute viral bronchiolitis. Archives of Disease in Childhood 1985; 60(11): 1064.

7. Burney PG, Chinn S, Rona RJ. Has the prevalence of asthma increased in children? Evidence from the national study of health and growth 1973-86. British medical journal 1990; 300(6735): 1306.
8. The International Study of, A. and C. Allergies in Childhood Steering, Worldwide variation in prevalence of symptoms of asthma, allergic rhinoconjunctivitis, and atopic eczema: ISAAC. Lancet 1998; 351:1225-1232.

9. Anderson H R, Butland B K, Strachan D P. Trends in prevalence and severity of childhood asthma. Bmj, 1994; 308(6944): 1600.

10. Lemanske Jr, Busse WW, Allergic disorders 6. Asthma. J Allergy Clin Immunol 2003; 111(2).

11. Pal R, Dahal S, Pal S et al. Prevalence of bronchial asthma in Indian children. Indian Journal of Community Medicine: Official Publication of Indian Association of Preventive \& Social Medicine 2009; 34(4): 310.

12. Woolcock A J, Konthen P G, Sedgwick C J. Allergic status of children in an Indonesian village. 1984.

13. SY. Recent status of clinical allergy in people's Republic of China. Sino-Jpn J Allergol immunol 1985;(2): 97.

14. Asthma data, available at : http:// www.chestheart.org, accessed on May 5, 2010.

15. Kabir ML, Rahman F, Hasan MQ et al. Asthma, atopic eczema and allergic rhino-conjunctivitis in school children. Mymensingh medical journal: MMJ 2005; 14(1): 41.

16. Zaman $\mathrm{K}$, Takeuchi $\mathrm{H}$, Yunus $\mathrm{M}$ et al. Asthma in rural Bangladeshi children. Indian journal of pediatrics 2007; 74(6): 539-543.

17. Beggs PJ. Impacts of climate change on aeroallergens: past and future. Clinical \& Experimental Allergy 2004; 34(10): 1507-1513.

18. Tepper RS, Wright AL, Taussing LM et al. Physiological growth and development of the lung during the first year of life. Am Rev Respir Dis 1986;(134): 513-9.

19. Sears MR, Burrows B, Flannery EM et al. Atopy in childhood. I. Gender and allergen related risks for development of hay fever and asthma. Clinical \& Experimental Allergy 1993; 23(11): 941-948.

20. Nishima S, Fujiwara K, Hayashi S et al. Surveys on the prevalence of pediatric bronchial asthma in Japan: a comparison between the 1982, 1992, and 2002 survey conducted in the same region using same methodology. Allergol Int 2009;(58(1)): 37-53.

21. Ranabir P, Dahal S, Shryan P. Prevalence of Bronchial Asthma in Indian children. Indian Journal of Community Medicine 2009; vol 34(Issue 4).

22. Zaman $\mathrm{K}$, Baqui $\mathrm{AH}$, Yunus $\mathrm{M}$ et al. Acute respiratory infections in children: a community-based longitudinal study in rural Bangladesh. J Trop Pediatr 1997; 43(3): 133-7.

23. Sazawal S, Black RE. Meta-analysis of intervention trials on case-management of pneumonia in community settings. The Lancet 1992; 340(8818): 528-533.

24. Henderson J,Hilliard TN, Sheriff A et al. Hospitalization for RSV bronchiolitis before 12 months of age and subsequent asthma, atopy and wheeze: a longitudinal birth cohort study. Pediatric allergy and immunology 2005; 16(5):386-392.

25. Sigurs N, Per M, Bjarnason R et al. Severe respiratory syncytial virus bronchiolitis in infancy and asthma and allergy at age 13. American journal of respiratory and critical care medicine 2004; 200406-730OCv1.

26. Stein RT,Sherrill D, Morgan WJ et al. Respiratory syncytial virus in early life and risk of wheeze and allergy by age 13 years. The Lancet 1999; 354(9178): 541-545.

27. Litonjua A A,Carey VJ, Burge $\mathrm{H}$ A et al. Parental history and the risk for childhood asthma. Does mother confer more risk than father? American journal of respiratory and critical care medicine 1998; 158(1): 176.

28. Murray A B, Morrison B J. Passive smoking and the seasonal difference of severity of asthma in children. Chest 1988; 94(4): p. 701. 